\title{
Resilience of the health team in caring for people with mental disorders in a psychiatric hospital
}

\author{
Resiliência da equipe de saúde no cuidado a pessoas com \\ transtornos mentais em um hospital psiquiátrico \\ Resiliencia del equipo sanitario en el cuidado a personas con \\ trastornos mentales en un hospital psiquiátrico
}

Débora Felippe Brolese ${ }^{1}$, Greice Lessa루, José Luís Guedes dos Santos², Jucimara da Silva Mendes ${ }^{1}$, Kamylla Santos da Cunha $^{3}$, Jeferson Rodrigues ${ }^{2}$

How to cite this article:

Brolese DF, Lessa G, Santos JLG, Mendes JS, Cunha KS, Rodrigues J. Resilience of the health team in caring for people with mental disorders in a psychiatric hospital. Rev Esc Enferm USP. 2017;51:e03230. DOI: http://dx.doi.org/10.1590/S1980-220X2016026003230

${ }^{1}$ Centro Universitário Barriga Verde, Orleans, SC, Brazil.

${ }^{2}$ Universidade Federal de Santa Catarina, Centro de Ciências da Saúde, Departamento de Enfermagem, Florianópolis, SC, Brazil.

${ }^{3}$ Universidade Federal de Santa Catarina, Centro de Ciências da Saúde, Programa de Pós-Graduação em Enfermagem, Florianópolis, SC, Brazil.

\section{Corresponding author:}

Greice Lessa

Centro Universitário Barriga Verde -

UNIBAVE - Coordenação de Enfermagem

Rua Pe. João Leonir Dall'Alba, 601

Bairro Murialdo

CEP 88870-000 - Orleans, SC, Brazil

greicelessa@hotmail.com

\begin{abstract}
Objective: Evaluating and understanding the resilience process of the health team in caring for people with mental disorders in a psychiatric hospital. Method: A mixedmethod study with concomitant triangulation of data from a cross-sectional study, with health professionals, and Grounded Theory in the data. Quantitative data were collected using the Resilience Scale and analyzed using descriptive and inferential statistics. Qualitative data were obtained from interviews and analyzed using initial and focused coding. Results: 40 health professionals participated in the study. Mean responses of the participants in the resilience scale were $99.80 \pm 12.86$ points, with a minimum of 35 and a maximum of 114 points. From the qualitative data, we can highlight the professionals' commitment in developing competencies in caring for people with mental disorders; valorization of teamwork and positive impact on work for the re-signification of the meaning of life. Conclusion: Understanding this process of resilience enables developing strategies to improve the quality of life of workers in psychiatric hospitals.
\end{abstract}

\section{DESCRIPTORS}

Resilience, Psychological; Patient Care Team; Psychiatric Nursing; Health Personnel; Mental Health. 


\section{INTRODUCTION}

The word resilience refers to an individual's ability to keep going well in the face of stressful and conflicting situations. It is a term originating in Latin, in which the word resilio means the return to an earlier state. In Engineering and Physics, it is used to express the capacity of a physical body to return to normal state, after suffering pressure on itself. From the 2000s, this concept has been transposed and diffused into the humanities to describe the potential of a person or group of people to construct or rebuild positively even in an adverse and unfavorable environment ${ }^{(1-2)}$.

In the context of work, resilience is a constant process, marked by personal growth and the development of people's potential for promoting worker health ${ }^{(3-4)}$. Thus, it is necessary for professionals to recognize their limitations so that they can partially or totally minimize unnecessary stressors and thus create skills and suggestions for improving their quality of life and professional performance ${ }^{(4-5)}$. In this context, the worker who uses his personal characteristics and his physical and mental balance is more likely to endure the rhythm of exhausting work, pressure and responsibilities, thus becoming a resilient professional ${ }^{(3)}$.

Among the professional categories, health workers have been consistently pointed out as a group at risk for physical and mental illness. In their daily work, health professionals are faced with people or groups that are in limited and complex situations, for example, sexual violence, hunger, abandonment, and misery (among others), which can generate anguish among the professionals and contribute to the appearance of functional diseases. Moreover, a number of organizational factors can impact working conditions in health, such as professional shortages, lack of autonomy, harassment and violence. All these factors contribute to the formation of a work environment that can be considered hostile, abusive and unpleasant ${ }^{(2,5)}$.

Despite being exposed to adverse conditions, many health professionals develop strategies and resources to remain healthy, which can make them satisfied with the environment and thus act significantly in promoting biopsychosocial well-being ${ }^{(3)}$. However, some workers suffer from functional illnesses and are unable to follow their personal and professional perspectives. In this sense, resilience is linked to the understanding of risk and protection factors. Risk factors reduce the possibility of overcoming imposed deficiencies, however their impact is diminished by protective factors ${ }^{(2,5)}$.

In the context of mental health care, psychiatric hospitals are one of the services responsible for attending people in psychological crisis, requiring professionals to be sensitive, alert, attentive and prepared to cope with the unpredictability of a variety of clinical conditions. As a consequence, these professionals are exposed to a series of physical and psychological workloads, which lead to wear, suffering and occupational stress. In addition, there are also difficulties in relation to organizational issues such as insufficient human resources and materials for adequate care ${ }^{(6)}$.

In this sense, we highlight the relevance of investigating the resilience process of health professionals caring for people with mental disorders in a psychiatric hospital. A study with this focus can contribute to systematizing and sharing strategies developed by the health team for working in the mental health field, and will help foster best practices for psychiatric care. Thus, the research questions of this study were: What is the resilience level of health professionals in a psychiatric hospital? What strategies do these workers develop for professional resilience?

Therefore, the objective of this study was to evaluate and understand the resilience process of the health team caring for people with mental disorders in a psychiatric hospital.

\section{METHOD}

This is a mixed method study implementing concomitant data triangulation which allows for simultaneous collection of quantitative and qualitative data, aiming at identifying convergences, differences or combinations between the data at the time of data analysis ${ }^{(7)}$. Thus, a quantitative study was carried out with a cross-sectional design and qualitative research based on the constructivist perspective of the Grounded Theory $(\mathrm{GT})^{(8)}$.

The study scenario was a psychiatric hospital located in Criciúma, in the south of the State of Santa Catarina, Brazil. It is a private institution with 205 beds serving/attending the Unified Brazilian Health System (Sistema Unico de Saúde SUS), caring for people with psychoactive substance abuse and serious mental disorders. The clinical staff of the institution consists of 52 health professionals: five nurses, 33 nursing technicians, nine physicians, one nutritionist, one social worker, one physical educator, one psychologist and one pharmacist.

Quantitative data were collected through two instruments: 1) a questionnaire with socio-professional variables (age, gender, marital status, occupation and experience in the institution); 2) scale for measuring resilience.

The adopted resilience scale is an adaptation of the Wagnild \& Young Resilience Scale ${ }^{(9)}$, validated for use in Brazil $^{(10)}$. The original instrument was comprised of 25 (twenty-five) items analyzed using a seven-point Likert scale. In this study, the adopted and adapted scale was also composed of 25 questions, however we chose to use a fivepoint Likert scale: (1) I strongly disagree, (2) I disagree, (3) Neither agree nor disagree, (4) I agree and (5) I strongly agree. The five-point scale has the same accuracy and is easier and faster to use than the seven-point scale ${ }^{(11)}$.

The scale is divided into three factors: Factor I (Resolutions of Actions and Values), Factor II (Independence and determination) and Factor III (Self-confidence and ability to adapt to situations). The score varies from 25 to 125 points as analyzed by factor and the total, where higher scores indicate higher resilience ${ }^{(9-10)}$.

All 52 members of the health team were invited to participate in the quantitative study upon invitation and handed out the data collection instruments during the work shift. The inclusion criterion was working at the institution for at least 1 month, considering this the necessary period for the worker to adapt in the work context. Absent professionals, on leave or on vacation during the data collection period were excluded from the study.

The final research sample consisted of 40 health professionals who had correctly filled out and returned the 
questionnaires to the responsible researcher, corresponding to $76.9 \%$ of the accessed population. The remaining 12 professionals did not return the questionnaire.

Quantitative data analysis was performed using descriptive and inferential statistics in the Statistical Package for Social Sciences (SPSS) software for Windows, version 20.0. Descriptive variables were presented in the form of tables with absolute (n) and relative (\%) frequencies. Continuous data were presented as mean and standard deviation. Student's t-test and ANOVA test were used for crossing the variables, considering the general score attributed to gender, age group, profession, marital status and length of experience. The level of significance was set at $\mathrm{p}<0.05$.

Qualitative data collection was concomitantly carried out with the quantitative study. Two Sample Groups (SG) were constituted totaling 26 participants in order to compose the theoretical sample of the GT. The first SG corresponded to the nursing team, with three nurses and 14 nursing technicians (P1-P17). The second SG was composed of nine professionals from the health team, including five physicians, one psychologist, one pharmacist, one social worker and one physical educator (P18-P26). The total number of participants was defined by theoretical saturation of the data. P1-P26 codes were composed from the initial letter of the word "participant" associated with numbers according to the order of the interviews.

Qualitative data were collected through intensive interviews which were recorded and transcribed in full. Duration of the interviews ranged from 20 minutes to 1 hour and 13 minutes. Intensive interviews were composed of open questions that explored aspects related to the work context and resilience strategies developed by health professionals.

Data analysis was performed using the $\mathrm{NVIVO}^{\circledR} 10$ software through initial and focused coding ${ }^{(8)}$. Initial coding studies the data fragments (words, lines, segments, and incidents), transforming them into codes. In focused coding, the codes of the first step are grouped until obtaining subcategories and categories ${ }^{(8)}$. In this study, we present the category entitled: "Becoming resilient to care for people with mental disorders in a psychiatric hospital".

The research project was approved by the Research Ethics Committee of the reference institution (Process no1.165.995 and CAAE: 46210015.5.0000.5598) and the study participants signed the Free and Informed Consent Form. The study was developed between the months of August and December,2015.

\section{RESULTS}

A total of 40 health professionals participated in the study. The majority (42.5\%) was aged between 31 and 43 years, males (52.5\%) and married (50\%). The sample included professionals from different professional categories, with an emphasis on nursing technicians (67.5\%). Regarding the experience in the institution, the majority (40\%) of the participants worked for less than 1 year in the service. Overall socioprofessional characteristics of the participants are presented in Table 1.

In the resilience scale, the summed mean of the participants' responses was $99.80 \pm 12.86$ points, the median was 108 , the minimum was 35 and the maximum was 114 points.
Table 1 - Socioprofessional characteristics of the participants Criciúma, Santa Catarina, Brazil, 2015.

\begin{tabular}{|c|c|c|c|}
\hline Variables & & $\mathbf{n}$ & $\%$ \\
\hline \multirow{4}{*}{ Age (classified) } & 18 to 30 years & 13 & 32.5 \\
\hline & 31 to 43 years & 17 & 42.5 \\
\hline & 44 to 56 years & 8 & 20.0 \\
\hline & $\geq 57$ years & 2 & 5.0 \\
\hline \multirow{2}{*}{ Gender } & Male & 21 & 52.5 \\
\hline & Female & 19 & 47.5 \\
\hline \multirow{3}{*}{ Marital status } & Married & 20 & 50.0 \\
\hline & Single & 15 & 37.5 \\
\hline & Divorced & 5 & 12.5 \\
\hline \multirow{7}{*}{ Occupation } & Nursing technician & 27 & 67.5 \\
\hline & Physician & 5 & 12.5 \\
\hline & Nurse & 4 & 10.0 \\
\hline & Pharmacist & 1 & 2.5 \\
\hline & Psychologist & 1 & 2.5 \\
\hline & Social worker & 1 & 2.5 \\
\hline & Physical educator & 1 & 2.5 \\
\hline \multirow{4}{*}{$\begin{array}{l}\text { Experience in the } \\
\text { institution }\end{array}$} & $\leq 1$ year & 16 & 40 \\
\hline & 1 to 5 years & 4 & 10.0 \\
\hline & 6 to 10 years & 8 & 20.0 \\
\hline & $\geq 10$ years & 12 & 30.0 \\
\hline
\end{tabular}

Note: $(n=40)$.

Among the socioprofessional variables analyzed, no statistically significant association with the level of resilience was identified. However, we found that the youngest and those with the shortest service time had higher scores than the rest of the group. Regarding occupation, nursing technicians obtained inferior scores in comparison to all the other professional categories.

The means of the Resilience Scale factors and their respective items are presented in Table 2 . The averages of the items ranged from 1.9 to 4.72. Among the three factors, "Factor II - Independence and Determination" presented the highest mean. This indicates that ideas of independence and determination are the main strategies used by participants to psychosocially adapt.

Table 2 - Mean factors of Resilience Scale - Criciúma, Santa Catarina, Brazil, 2015.

\begin{tabular}{lcc}
\hline \multicolumn{1}{c}{ Factor/items } & Mean & SD \\
\hline Factor I - Resolutions of Actions and Values & 3.96 & $\mathbf{0 . 5 3}$ \\
\hline 1. When I make plans, I follow through with them & 4.40 & 0.93 \\
2. I usually manage one way or another & 2.75 & 1.84 \\
6. I feel proud that I have accomplished things in life & 4.60 & 0.98 \\
\hline & & continued...
\end{tabular}




\begin{tabular}{|c|c|c|}
\hline Factor/items & Mean & SD \\
\hline 7. I usually take things in stride & 2.88 & 1.52 \\
\hline 8. I am friends with myself & 4.53 & 1.13 \\
\hline 10. I am determined & 4.63 & 0.92 \\
\hline 11. I seldom wonder what the point of it all is & 1.90 & 1.32 \\
\hline 12. I take things one day at a time & 3.28 & 1.52 \\
\hline 14. I have self-discipline & 4.35 & 1.00 \\
\hline 16. I can usually find something to laugh about & 3.65 & 1.41 \\
\hline $\begin{array}{l}\text { 18. In an emergency, I'm someone people can } \\
\text { generally rely on }\end{array}$ & 4.68 & 0.83 \\
\hline $\begin{array}{l}\text { 19. I can usually look at a situation in a number of } \\
\text { ways }\end{array}$ & 4.38 & 1.05 \\
\hline 21. My life has meaning & 4.72 & 0.78 \\
\hline $\begin{array}{l}\text { 23. When I'm in a difficult situation, I can usually find } \\
\text { my way out of it }\end{array}$ & 4.35 & 1.00 \\
\hline 24. I have enough energy to do what I have to do & 4.45 & 0.81 \\
\hline Factor II - Independence and Determination & 4.29 & 0.71 \\
\hline 4. Keeping interested in things is important to me & 4.45 & 0.99 \\
\hline 5. I can be on my own if I have to & 3.98 & 1.14 \\
\hline 15. I keep interested in things & 4.42 & 1.15 \\
\hline 25. It's okay if there are people who don't like me & 4.33 & 1.00 \\
\hline $\begin{array}{l}\text { Factor III - Self-confidence and ability to adapt to } \\
\text { situations }\end{array}$ & 3.85 & 0.60 \\
\hline $\begin{array}{l}\text { 3. I am able to depend on myself more than anyone } \\
\text { else }\end{array}$ & 4.00 & 1.22 \\
\hline 9. I feel that I can handle many things at a time & 3.40 & 1.46 \\
\hline $\begin{array}{l}\text { 13. I can get through difficult times because I've } \\
\text { experienced difficulty before }\end{array}$ & 4.55 & 0.88 \\
\hline 17. My belief in myself gets me through hard times & 4.20 & 1.26 \\
\hline $\begin{array}{l}\text { 20. Sometimes I make myself to do things whether I } \\
\text { want to or not }\end{array}$ & 3.42 & 1.50 \\
\hline $\begin{array}{l}\text { 22. I do not dwell on things that I can't do anything } \\
\text { about }\end{array}$ & 3.52 & 1.41 \\
\hline
\end{tabular}

Source: Pesce et al. $(2005)^{(10)}$.

From the qualitative study and based on the process of coding and categorizing the data, we can highlight the category titled: Becoming resilient to care for people with mental disorders in a psychiatric hospital. This category presents five subcategories, which bring forth the main convergences and differences in relation to the quantitative results: (1) Developing skills to care for people with mental disorders; (2) Emphasizing the importance of teamwork; (3) Facing prejudice for working with "crazy people"; (4) Attempting to separate professional life from personal life; and, (5) Re-signifying the meaning of life and interpersonal relationships. Each one is presented next.

\section{DeVeloping SKILlLS to CARE fOR PeOPle WITH MENTAL DISORDERS}

Professionals have learned to care for people with mental disorders from their own professional experience in this area. In this sense, they emphasized the need for a professional qualification course, mainly due to the difficulty of correlating theory and practice in mental health throughout academic training. Although this is expected since health training is generalized, and specialized service requires training through courses or permanent education.

(...) we are far away from a more qualified course for this area of nursing, on handling the patient (P27).

(...) because I've worked in a hospital before, I worked a long time in the hospital and I had never worked with a psychiatric patient. It is totally different, and when we take the course we do not have this practical part (...) and now it is totally different experiencing this practice $(\mathrm{P} 4)$.

Among the competencies for professional work in the field of mental health, we can emphasize the importance of developing behaviors and attitudes, with an emphasis on patience, flexibility, agility, prudence and dedication, which allows for building/creating a bond with the patient.

We have to be agile, prudent (...) these are qualities that need to be intrinsic in the professional who works in a psychiatric hospital (P23).

We end up having to be very flexible, to deal with very different situations, and this ends up causing us to play it by ear (P11).

The first thing is patience, because some patients you need to ask them ten times what are they feeling so you can get a response. Not everyone has the patience for that (P9).

I liked one of them so much. I like them all, but there's always one that is special, one that you feel attached to, he was my "darling" (...) (P3).

\section{EMPHASIZING THE IMPORTANCE OF TEAMWORK}

Mental health work is complex, because each person has a unique demand for care depending on the signs and symptoms presented. In this sense, multiprofessional teamwork contributes to organizing and responding to this complexity, which is multi-determined. When a person is hospitalized in a psychiatric hospital, they may be subjectively disorganized and they often cannot take care of themselves, in addition to the effects of the drugs which at first demand more careful monitoring by the team.

Psychiatric patients require medication, monitoring by a psychologist, social worker, nurses, physicians and technicians, hygiene staff. It's a whole team that has to struggle/work together. And if you do not follow them closely, it's complicated (P5).

Our work here would be the care, care for them not to get hurt, for them not to fall, we must always be aware and we have to work as a team, because one cannot work miracles alone (P15).

I perform the more bureaucratic tasks, preparing medication, sorting through medical records for medical examinations and exams, but the people who are on the floor who do the rounds, they take care of the TV room; they are our colleagues (P10).

\section{FACING PREJUDICE FOR WORKING WITH "CRAZY PEOPLE"}

The professionals reported suffering prejudice for caring for patients with mental disorders, which generates a negative social acceptance. This prejudice is justified by the pejorative character ("crazy people") attributed by common sense to those people in psychological suffering. 
Isuffer a lot, a lot of people are prejudiced, "Ob! You work with crazy people!"You know, they use those terms. (...) People speak about it without any interest, you have to be inside, you have to come here, you have to see it, you have to experience it to understand (P8).

(...) Just mentioning or saying that you work here, "Ob my God, they're all crazy out there." I always say that: "You only have the knowledge, but you have no vision. Because if you went there, you would see that it is totally different, it is very different from what you think" (P25).

\section{Attempting to SePARATE PROFESSIONAL life FROM PERSONAL LIFE}

Developing resilience requires professionals to seek psychological self-control, which enables them to separate the problems and difficulties experienced in the work environment from their private lives.

Do not bring any of this home, because it ends up really disturbing your relationships with other people outside here (P10).

One difficulty is perhaps is dealing with their problems (...) to the point of it being a difficulty because you end up bringing it to yourself, you end up feeling kind of indignant (P29).
We try to make sure this does not affect our work, but we try to overcome these difficulties (P17).

\section{RE-SIGNIFYING THE MEANING OF LIFE}

Working with people with mental disorders enables professionals to mature and develop in person, valuing social/family life, and as a consequence, developing a new meaning of life. Changes happen from living with needy individuals who are often abandoned by family members or excluded from society.

It certainly transformed me, it totally changes us, it actually makes us better, more mature (...) it also minimizes the idea that sometimes we have of a problem that we think is a big deal, when it is nothing compared to what real problems are (P11).

I cannot even say that I am the same person as when I first entered an institution (...) all this favors our growth as people (P24).

(...) we start giving more value to our feelings, to people, to relationships, to bonds (P14).

Figure 1 shows the articulation between the quantitative and qualitative results.

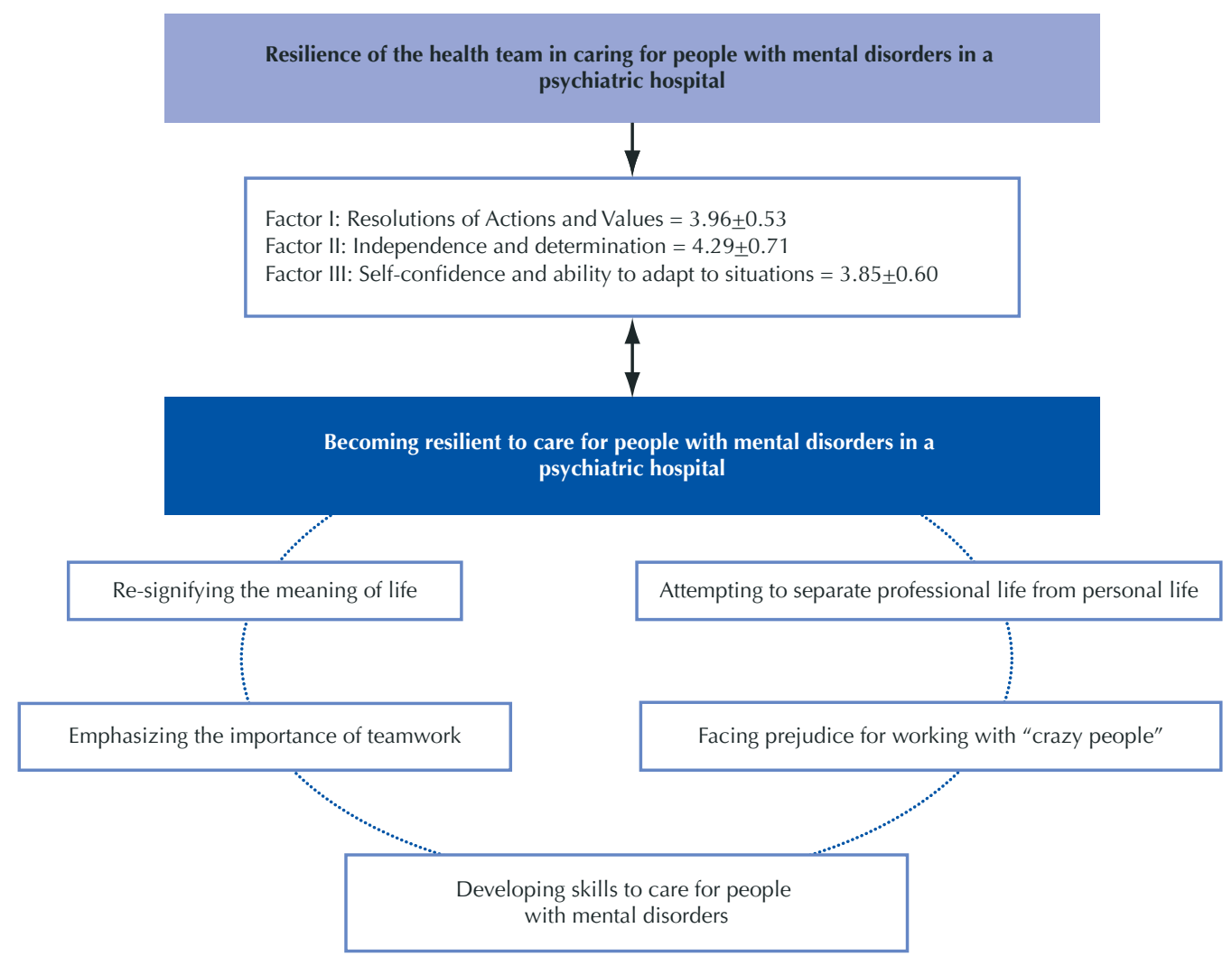

Figure 1 - Representative diagram of the articulation between the quantitative and qualitative results - Criciúma, SC, Brazil, 2015.

\section{DISCUSSION}

Integrating the quantitative and qualitative results made it possible to evaluate and understand the resilience process in the health team who care for people with mental disorders in a psychiatric hospital. This occurred by identifying convergences, differences or combinations between the obtained data.
Among the three factors of the resilience scale, the highest mean was identified for Factor II - Independence and Determination; indicating that ideas of independence and determination are the main strategies used by participants to adapt in the psychosocial field. Factor III-Self-confidence and ability to adapt to situations obtained the lowest mean, which 
corresponds to the aspects related to friendship, personal fulfillment, satisfaction and meaning of life. These results diverge from the findings of a study with resident physicians of a school hospital in the city of São Paulo, where a high resilience was identified in relation to the self-confidence domain as a personality trait ${ }^{(12)}$.

Regarding the association between socio-professional variables and the level of resilience, we found that younger professionals with less experience obtained higher resilience scores than the rest of the group. The predominance in this class may be associated with enthusiasm at the beginning of their professional career, the discovery of new challenges, including affinity for the performance area. In contrast, a study developed in Ireland ${ }^{(13)}$ identified that older and experienced professionals have greater resilience when working in stressful environments, since they have greater organizational and emotional control capacity when dealing with occupational demands.

Another relevant finding was that nursing technicians had lower resilience averages compared to higher level professionals. This result may be related to their participation in caring for patients throughout the 24 hours day in the hospital context, which represents greater physical and psychological demands at work. Moreover, lower levels of education and professional training may hinder the development of strategies for controlling the emotional wear and tear resulting from professional practice ${ }^{(14-15)}$.

The qualitative results highlight the search for developing therapeutic skills, which seek to associate technicalscientific knowledge with characteristics such as patience and prudence. A study on the training and qualification of mental health service professionals corroborates these results, highlighting the importance of skills and attitudes towards acts of listening, welcoming, availability and commitment to work in the area of mental health ${ }^{(16)}$. A study with nurses from psychiatric units conducted in Japan also showed the commitment of these professionals to provide an environment of care conducive to patients, seeking to understand their reactions as well as their thoughts and feelings ${ }^{(17)}$.

The interviewed professionals also emphasized the importance of team work to care for people with mental disorders. A study on job satisfaction in Psychosocial Care Centers in Southern Brazil has identified the importance of the relationships established in the work team and decentralized and democratic managerial processes for job satisfaction ${ }^{(18)}$. The multiprofessional work anchored in interaction between professionals must be horizontal and interrelated, so that the team is integrated, thereby expanding knowledge without a professional having greater or less importance in providing the necessary and quality care to the patient ${ }^{(19)}$.

A study about the view of nursing professionals on the structural and contextual dimensions of Psychosocial Care Centers in the State of São Paulo, Brazil, has confirmed the importance of teamwork in overcoming and solving difficulties at work ${ }^{(20)}$. Similarly, a study carried out in two psychiatric hospitals in Belgium showed that teamwork, especially good relationships between nurses and physicians, is an aspect that favors the professional practice nursing environment and contributes to greater job satisfaction ${ }^{(21)}$.

A study with Australian nurses who self-perceived themselves as resilient, identified the importance of teamwork as one of the main motivators in the work environment, configuring itself as a coping strategy in the face of adversity at work ${ }^{(22)}$. Regarding teamwork in nursing, it is worth noting that sharing decision-making processes enhances co-responsibility between nurses and nursing technicians, which can favor communication and avoid conflicts in the work environment ${ }^{(23)}$.

As a negative aspect of the work, the participants highlighted the prejudice induced by people in their own social life as a result of their professional performance in a psychiatric hospital. The prejudice perceived by the participants can explain the low mean of item 7 of Factor I of the Resilience Scale, which refers to the ability of the professional in dealing with and accepting occupational demands without aggravating their suffering. Despite the Psychiatric Reform advancement and searching to transform the social mindset in relation to the mentally ill, negative social representations about people with mental disorders are still present in the different corporate segments. Transforming the social stigma associated with mental disorders requires developing joint actions by professionals of the mental health services and the relatives of the mentally ill in order to clarify mental illnesses, as well as to promote the conviviality and the respect to the difference ${ }^{(20,24)}$.

The routine of working in a psychiatric institution is very challenging and can generate diverse forms of illness, stress, physical and psychological wear among health professionals. In this way, professionals use the most varied types of defense to face their daily work and become more resilient ${ }^{(3)}$. In this study, the participants' preoccupation with separating their professional lives from their personal may be highlighted, avoiding involvement with the patients' problems beyond the working environment.

In the qualitative results, the participants showed a constant search for adaptation to the work situations, despite the lower mean of Factor III in relation to the other resilience scale factors. In this sense, we highlight re-signification as a strategy used by professionals to adapt to the work context, which allows them to successfully overcome difficulties and perceive personal and professional maturation through caring for people with mental disorders. Similarly, the importance of work affecting personal and professional maturation was also described by a study with nursing professionals from a hospital in the Rio Pardo Valley region of Rio Grande do Sul, Brazil ${ }^{(5)}$.

\section{CONCLUSION}

This study allowed for evaluating and understanding the health team's resilience process in caring for people with mental disorders in a psychiatric hospital through integrating quantitative and qualitative data. In the quantitative study, we identified that the summed mean of participants' responses on the resilience scale was $99.80 \pm 12.86$ points, the median was 108 , the minimum was 35 , and the maximum was 114 points. Based on the qualitative data, it may be observed that 
the resilience of health professionals is related to developing therapeutic skills, valorizing teamwork and overcoming prejudice faced regarding the work done. In the personal scope, we highlight the attempt to separate work from personal life, as well as the positive impact of professional practice on how they perceive life and interpersonal relationships.

Professionals who work in a psychiatric environment are more exposed to physical and mental exhaustion, which makes resilience a constant challenge. In this sense, teamwork favors self-resilience insofar as the relationship with another professional reflects their own weaknesses and potentialities, contributing to a resilient praxis. We emphasize that resilience can be even more potent when professionals guide their practice on the tripod of mental health training: therapy/ personal analysis, clinical supervision of cases attended and theoretical study of the chosen clinical approach.

The results presented can contribute to professional practice and research fields in the area of nursing and health workers' health, especially in the context of psychiatric hospital care. In professional practice, research can foster discussions and reflections among health professionals, managers and class entities on the importance of developing strategies to enhance resilience and improve the quality of life of workers working in psychiatric hospitals. In the research field, this research may provide support for future studies that advance the discussion of the studied problem. Moreover, this study may also guide other researchers/ studies regarding the use of mixed methods in health and nursing research.

Finally, we can point out that the study presents limitations on the composed quantitative sample $(n=40)$. Also, generalizations from the presented results should be made with caution, considering that data were collected from a single scenario. Further studies including a larger number of participants and other scenarios could generate more representative information on the investigated phenomenon.

\section{RESUMO}

Objetivo: Avaliar e compreender o processo de resiliência da equipe de saúde no cuidado a pessoas com transtornos mentais em um hospital psiquiátrico. Método: Estudo de método misto com triangulação concomitante de dados de um estudo transversal, com profissionais de saúde, e uma Teoria Fundamentada nos Dados. Os dados quantitativos foram coletados a partir da Escala de Resiliência e analisados por meio de estatística descritiva e inferencial. Os dados qualitativos foram obtidos a partir de entrevistas e analisados mediante codificação inicial e focalizada. Resultados: Participaram da pesquisa 40 profissionais de saúde. Na escala de resiliência, a média das respostas dos participantes foi 99,80£12,86 pontos, o mínimo foi de 35 e o máximo de 114 pontos. Nos dados qualitativos, destacaram-se o empenho dos profissionais para o desenvolvimento de competências para o cuidado de pessoas com transtornos mentais, a valorização do trabalho em equipe e o impacto positivo no trabalho para a ressignificação do sentido da vida. Conclusão: $\mathrm{O}$ entendimento desse processo de resiliência possibilita o desenvolvimento de estratégias para a melhoria da qualidade de vida dos trabalhadores que atuam em hospitais psiquiátricos.

\section{DESCRITORES}

Resiliência Psicológica; Equipe de Assistência ao Paciente; Enfermagem Psiquiátrica; Pessoal de Saúde; Saúde Mental.

\section{RESUMEN}

Objetivo: Evaluar y comprender el proceso de resiliencia del equipo sanitario en el cuidado a personas con trastornos mentales en un hospital psiquiátrico. Método: Estudio de método mixto con triangulación concomitante de datos de un estudio transversal, con profesionales sanitarios, y una Teoría Fundamentada en los Datos. Los datos cuantitativos fueron recogidos a partir de la Escala de Resiliencia y analizados mediante la estadística descriptiva e inferencial. Los datos cualitativos fueron obtenidos a partir de entrevistas y analizados mediante codificación inicial y focalizada. Resultados: Participaron en la investigación 40 profesionales sanitarios. En la escala de resiliencia, el promedio de las respuestas de los participantes fue 99,80 12,86 puntos, el mínimo fue de 35 y el máximo de 114 puntos. En los datos cualitativos, se destacaron el empeño de los profesionales para el desarrollo de competencias para el cuidado de personas con trastornos mentales, la valorización del trabajo en equipo y el impacto positivo en el trabajo para la resignificación del sentido de la vida. Conclusión: El entendimiento de dicho proceso de resiliencia posibilita el desarrollo de estrategias para la mejoría de la calidad de vida de los trabajadores que actúan en hospitales psiquiátricos.

\section{DESCRIPTORES}

Resiliencia Psicológica; Grupo de Atención al Paciente; Enfermería Psiquiátrica; Personal de Salud; Salud Mental.

\section{REFERENCES}

1. McCann CM, Beddoe E, McCormick K, Huggard P, Kedge S, Adamson C, et al. Resilience in the health professions: a review of recent literature. Int J Wellbeing. 2013;3(1):60-81.

2. Arrogante O. Resiliencia en enfermería: definición, evidencia empírica e intervenciones. Index Enferm. 2015;24(4):232-35.

3. Ribeiro RP, Martins JT, Marziale MHP, Robazzi MLCC. Work-related illness in nursing: an integrative review. Rev Esc Enferm USP. 2012;46(2):495-504. DOI: http://dx.doi.org/10.1590/ S0080-62342012000200031

4. Fischborn AF, Viegas MF. A atividade dos trabalhadores de enfermagem numa unidade hospitalar: entre normas e renormalizações. Trab Educ Saúde. 2015;13(3): 657-74.

5. Sousa VFS, Araujo TCCF. Estresse ocupacional e resiliência entre profissionais de saúde. Psicol Ciênc Profissão. 2015;35(3):900-15. 
6. Souza SRC, Oliveira EB, Mauro MYC, Mello R; Kestemberg CCF, Paula GS. Cargas de trabalho de enfermagem em unidade de internação psiquiátrica e a saúde do trabalhador. Rev Enferm UERJ. 2015;23(5):633-8.

7. Fetters MD, Curry LA, Creswell JW. Achieving integration in mixed methods designs - principles and practices. Health Serv Res. 2013;48(6 pt2):2134-56.

8. Charmaz KA. Construção da teoria fundamentada. Porto Alegre: Artmed; 2009.

9. Wagnild GM, Young, H. Development and psychometric evaluation of the resilience scale. J Nurs Meas. 1993;1(2):165-78.

10. Pesce RP, Assis SG, Avanci JQ. Santos NC, Malaquias JV, Carvalhaes R. Adaptação transcultural, confiabilidade e validade da escala de resiliência. Cad Saúde Pública 2005;21(2):436-48.

11. Revilla MA, Saris WE, Krosnick JA. Choosing the number of categories in agree-disagree scales. Sociol Methods Res. 2013;43(1):73-97.

12. Rodrigues RTS, Barbosa GS, Chiavone PA. Personalidade e resiliência como proteção contra o Burnout em médicos residentes. Rev Bras Educ Med. 2013;37(2):245-53.

13. Healy S, Tyrrell M. Stress in emergency departments: experiences of nurses and doctors. Emerg Nurse. 2011;19(4):31-7.

14. Santana LL, Sarquis LMM, Brey C, Miranda FMDA, Felli VEA. Absenteísmo por transtornos mentais em trabalhadores de saúde em um hospital no sul do Brasil. Rev Gaúcha Enferm. 2016;37(1):e53485.

15. Bastos MA. O conceito de resiliência na perspectiva de Enfermagem. Rev Iberoam Educ Invest Enferm. 2013;3(4):61-70.

16. Silva NS, Espiridião E, Cavalcante ACG, Souza ACS, Silva KKC. Development of human resources for work in mental health services. Texto Contexto Enferm. 2013;22(4):1142-51.

17. Nagayama Y, Hasegawa M. Nursing care process for releasing psychiatric inpatients from long-term seclusion in Japan: modified grounded theory approach. Nurs Health Sci. 2014;16(3):284-90.

18. Lapischies SRC, Jardim VMR, Kantorski LP. Factors associated with satisfaction at work in Psychosocial Care Centers. Rev Latino Am Enfermagem. 2014;22(6):950-8.

19. Pinho LB, Kantorski LP, Olschoiwsky A, Schneider JF, Lacchini AJB. Ideology and mental health: analysis of the discourse of workers in the psychosocial area. Texto Contexto Enferm. 2014;23(1):65-73.

20. Ventura CAA, Moll MF, Araújo AS, Jorge MS. A enfermagem e as dimensões organizacionais de dois centros de atenção psicossocial. Cienc Cuid Saúde 2015; 14(2):1097-104.

21. Van Bogaert P, Wouters K, Willems R, Mondelaers M, Clarke S. Work engagement supports nurse workforce stability and quality of care: nursing team-level analysis in psychiatric hospitals. J Psychiatr Ment Health Nurs. 2013;20(8):679-86.

22. Mcdonald G, Jackson D, Vickers MH, Wilkes L. Surviving workplace adversity: a qualitative study of nurses and midwives and their strategies to increase personal resilience. J Nurs Manag. 2016;24(1):123-31.

23. Souza GC, Peduzzi M, Silva JAM, Carvalho BG. Teamwork in nursing: restricted to nursing professionals or an interprofessional collaboration? Rev Esc Enferm USP 2016;50(4): 642-49. DOI: http://dx.doi.org/10.1590/S0080-623420160000500015

24. Goodwin J, Tajjudin I. "What do you think i am? Crazy?" The joker and stigmatizing representations of mental ill-health. J Popular Culture. 2016;49(2):385-402. 